\title{
Effects of aluminum and moisture levels on aluminum bioaccumulation and protein content in the earthworm Octodrilus complanatus
}

\author{
D. Bilalis ${ }^{1 *}$, I. Tzortzi ${ }^{1}$, E. Vavoulidou ${ }^{2}$, A. Karkanis ${ }^{3}$, N. Emmanouel ${ }^{1}$, A. Efthimiadou ${ }^{4}$, N. Katsenios ${ }^{1}$, S. \\ Patsiali $^{1}$ and L. Dellaporta ${ }^{2}$
}

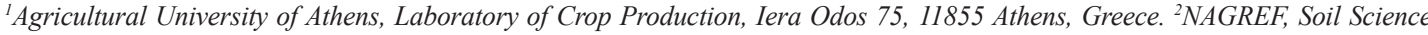
Institute, Lycovrisi, Attiki, Greece. ${ }^{3}$ University of Thessaly, Department of Agriculture Crop Production and Rural Environment, Fytokou Str, 38466, N. Ionia, Magnisia, Greece. ${ }^{4}$ Open University of Cyprus, Nicosia, Cyprus. "Corresponding author: bilalisdimitrios@yahoo.gr
\end{abstract}

\begin{abstract}
Laboratory experiments were conducted to determine the effects of soil aluminum levels and moisture content on aluminum (Al) bioaccumulation and protein content in the earthworm (Octodrilus complanatus). The experimental design was a completely randomized block with 2 factors (aluminum content [C-0: $0 \mathrm{mg} \mathrm{kg}^{-1}, \mathrm{C}-1: 1000 \mathrm{mg} \mathrm{kg}^{-1}$, C-2: $2000 \mathrm{mg} \mathrm{kg}^{-1}$, C-3: $3000 \mathrm{mg} \mathrm{kg}^{-1}$ ] and moisture level [M1: $100 \%$ of soil water capacity, $M 2: 60 \%$ of soil water capacity] and 3 replications. The lowest $\mathrm{pH}$ was noted in the $\mathrm{C}-0$ treatment. There were no significant differences in the electrical conductivity, cation exchange capacity or total nitrogen in soil between the aluminum treatments. Moreover, there were no significant differences in soil properties between the moisture treatments. The highest soil $\mathrm{Al}$ content was noted in the C-3 treatment. No earthworm mortality was observed in soil contaminated with Al. Moreover, the highest aluminum content in earthworms was observed in the C- 3 treatment. The aluminum content in the earthworms was significantly positively correlated with the aluminum content in the soil $\left(\mathrm{r}=0.984^{* * *}, p<0.001\right)$. Our results indicated that the growth of earthworms was affected by the Al level. Lastly, Al caused a reduction in earthworm protein content.
\end{abstract}

Keywords: Aluminum, bioaccumulation, bioindicator, earthworms, mortality 


\section{Introduction}

Earthworms are very important soil organisms. The earthworm Octodrilus complanatus (Oligochaeta, Lumbricidae) is a large species (Monroy et al., 2007) that is widely distributed along the Mediterranean basin (Pavlíček and Csuzdi, 2006). O. complanatus is commonly found in cultivated fields in Greece (Vavoulidou et al., 2010). Earthworms influence the soil quality (Lapied et al., 2009) and fertility (Bilalis et al., 2009; Ozawa et al., 2005).

Earthworms can also be used as bioindicators for soil pollution (Bullinger-Weber et al., 2012; Dureja et al., 1999; Suthar et al., 2008; Wang et al., 2009). In general, bioindicators are used to estimate the quality of the environment. Currently, soil pollution by heavy metals is widespread (Calisi et al., 2013; Garg et al., 2009). The accumulation of heavy metals and organic pollutants (e.g., pesticides) in earthworms is speciesdependent (Garg et al., 2009; van Vliet et al., 2005; Wu et al., 2011). Garg et al. (2009) reported that $\mathrm{Cr}$ and $\mathrm{Pb}$ concentrations were significantly higher in Allolobophora parva compared with Eisenia fetida, whereas accumulation of $\mathrm{Zn}$ was similar in both species.

Aluminum is a major component of soils. Moreover, aluminum toxicity is a major problem limiting plant growth and crop production in acidic soils (Seguel et al., 2013). Indeed, $\mathrm{Al}$ is solubilized to the toxic cation $\mathrm{Al}^{+3}$ in acidic soils $(\mathrm{pH} \leq 5)$ (Matsumoto et al., 2000). It is well known that $\mathrm{Al}^{+3}$ inhibit root growth (Ma et al., 2001). Only a few studies have investigated the effects of aluminum on soil organisms such as earthworms (van Gestel and Hoogerwerfa, 2001; Tejada et al., 2010; Zhang et al., 2013). Zhao and Qui (2010) reported that aluminum is toxic to earthworms $\left(\mathrm{LC}_{50}=532.33 \mathrm{Al} / \mathrm{kg}\right.$ dry soil $) . \quad$ Furthermore, earthworms can accumulate aluminum metal from polluted soils.

The aim of this study was to determine the effects of aluminum levels and moisture content on aluminum bioaccumulation and protein content in the earthworm Octodrilus complanatus, which is the dominant earthworm species in the Mediterranean basin and is used as a bioindicator in organic agriculture.

\section{Materials and Methods}

\subsection{Sample collection}

Ten soil samples from the research field (23.43E, $34.58 \mathrm{~N}$ ) of the Agricultural University of Athens were selected for random sampling to create a representative sample. Soil samples were obtained from the topmost layer $(0-20 \mathrm{~cm})$ in November 2009 . The soil was clay loam $(29.8 \%$ clay, $34.3 \%$ silt and $35.9 \%$ sand) with the following characteristics: $\mathrm{pH}, 7.29$; total $\mathrm{N}, 0.12 \%$; cation exchange capacity, 28.5 (meq/100 g); and $\mathrm{EC}, 1.60 \mathrm{mS} \mathrm{cm}{ }^{-1}$. The earthworms were purchased from the research field $(23.46 \mathrm{E}, 23.04 \mathrm{~N})$ of National Agricultural Research Foundation (NAGREF) in Licovrisi. The earthworms were collected by hand from squares $(50 \mathrm{~cm} \times 50 \mathrm{~cm} ; 10-20 \mathrm{~cm}$ depth$)$. At the time of sampling, the soil moisture content was at field capacity. Immediately after collection, the earthworms were taken to the laboratory in the soil from which they had been collected. Earthworms were washed and kept in plastic containers on wet filter paper. Part of each soil sample was air-dried at ambient temperature, crushed and sieved through a $2-\mathrm{mm}$ sieve to analyze soil $\mathrm{pH}$ and other physicochemical properties.

\subsection{Experimental design}

The laboratory experiments were conducted at the Agricultural University of Athens in 2009-2010. The experimental design was a completely randomized block with 2 factors (aluminum content and moisture level) and 3 replications. The aluminum treatments were as follows: $\mathrm{C}-0$, control (without aluminum); $\mathrm{C}-1,1000 \mathrm{mg} \mathrm{kg}^{-1}$; $-2,2000 \mathrm{mg} \mathrm{kg}{ }^{-1} ; \mathrm{C}-3,3000$ $\mathrm{mg} \mathrm{kg}{ }^{-1}$. The moisture treatments were as follows: 
$M 1,100 \%$ soil water capacity; $M 2,60 \%$ soil water capacity. The working Al solutions were prepared by diluting analytical aluminum hydroxide $(\mathrm{pH}=9.5)$ with deionized water. Plastic containers were used, and each container was filled with $1000 \mathrm{~g}$ of dried natural soil. Moreover, the containers were covered with a fine nylon mesh to keep the earthworms from escaping. The containers were incubated for 2 weeks after the addition of aluminum. Three earthworms of similar weight and $5 \mathrm{~g}$ of crushed dried leaves were added to each plastic container. Earthworms feed predominantly on organic material at the soil surface (Vavoulidou et al., 2009). The experiment was repeated twice. The water content in the container was kept constant by adding water weekly. The experiment was conducted for 50 days.

\subsection{Measurements and methods}

Soil properties

The soil samples were air-dried, sieved at $2 \mathrm{~mm}$ and analyzed to determine different soil properties $(\mathrm{pH}$, total nitrogen, electrical conductivity [EC], cation exchange capacity [CEC], exchangeable $\mathrm{Ca}$ and soil $\mathrm{Al}$ content). The $\mathrm{pH}$ and electrical conductivity were measured using water extracts obtained at a 1:1 soil:water ratio after shaking for $60 \mathrm{~min}$. The total nitrogen was determined by the Kjeldahl method (Bremner, 1960) using a Buchi 316 device to combust and extract the soil samples. Exchangeable $\mathrm{Ca}$ was measured by the Drouineau-Galet method using a spectrometer. Calcium cations were extracted with ammonium acetate solution. The cation exchange capacity was determined using the ammonium acetate method (Chapman, 1965). Lastly, aluminum cations were extracted with $1 \mathrm{M} \mathrm{KCl}$ solution (Edmeales et al., 1983), and the aluminum concentration was determined with a spectrophotometer.

\section{Earthworm traits}

Earthworms were removed from the containers and washed with distilled water to remove the soil particles attached to their skin. The weights of the earthworms were recorded at the beginning and end of the experiment. The earthworms were oven-dried (110 ${ }^{\circ} \mathrm{C}, 6 \mathrm{~h}$ ) to estimate their total nitrogen content via the Kjeldahl method (Ozawa et al., 2005). The earthworms were burned to ash, and the $\mathrm{Al}$ concentrations in the earthworms were measured using graphite furnace atomic absorption spectrometry (ISO, 1998; OECD, 2004). The protein concentration of the earthworms was determined by the dye binding method according to Bradford (1976). Final, mortality and survival were measured by counting the surviving worms in each container.

\subsection{Statistical analysis}

Statistica software (StatSoft Inc., Tulsa, OK, USA) was used to perform analysis of variance and comparisons among means. The Tukey test was used to detect and separate the mean treatment differences. Correlation analyses were used to describe the relationships between soil properties and earthworm characteristics. All comparisons were made at the 5\% level of significance.

\section{Results and Discussion}

\subsection{Soil properties}

Soil properties influence the availability of heavy metals in earthworms (Leveque et al., 2013; Suthar et al., 2008). Our results indicated that the lowest $\mathrm{pH}$ (Figure 1) occurred in the C- 0 treatment (control). Posthoc analysis by Tukey's test showed that there were also statistically significant differences between the C-2 and $\mathrm{C}-3$ treatments. The highest $\mathrm{pH}$ was observed in the $\mathrm{C}-3$ treatment. In addition, there were no significant differences in electrical conductivity, cation exchange capacity or total nitrogen between the aluminum treatments. Normally, the soil $\mathrm{pH}$ decreases when the aluminum content increases; however, the $\mathrm{pH}$ level of aluminum hydroxide is 9.5 . Thus, the $\mathrm{pH}$ was higher in the $\mathrm{C}-3$ treatment than in the control treatment. 

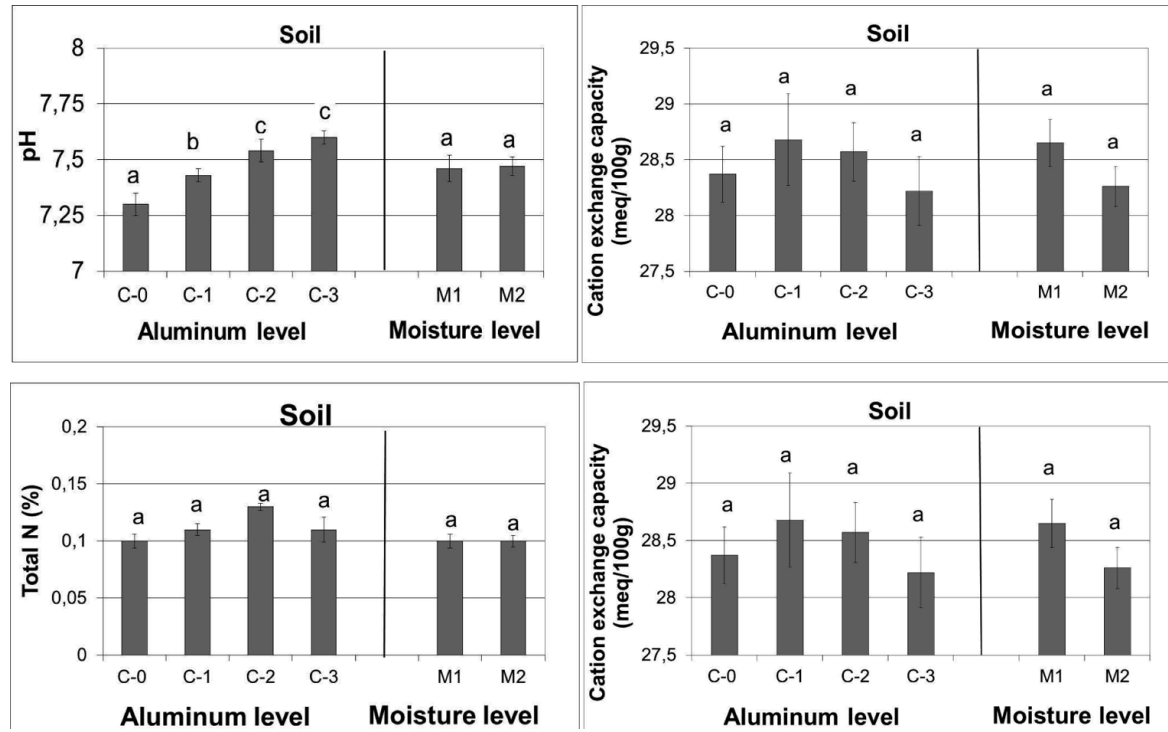

Figure 1. Effects of aluminum treatments (C-0: $\left.0 \mathrm{mg} \mathrm{kg}^{-1}, \mathrm{C}-1: 1000 \mathrm{mg} \mathrm{kg}^{-1}, \mathrm{C}-2: 2000 \mathrm{mg} \mathrm{kg}^{-1}, \mathrm{C}-3: 3000 \mathrm{mg} \mathrm{kg}^{-1}\right)$ and moisture level (M1: 100\% soil water capacity, M2: 60\% soil water capacity) on soil $\mathrm{pH}$, electrical conductivity $\left(\mathrm{mS} \mathrm{cm}^{-1}\right)$, cation exchange capacity (meq/100 g) and total $\mathrm{N}(\%)$. For each factor, columns followed by the same letter are not significantly different $(p \leq 0.05$, Tukey test). Bars indicate standard error.

Additionally, anions can adsorb onto the surface of aluminum oxides by ion-pair formation with positively charged surface sites or by ligand exchange with surface hydroxyls (Goldberg et al, 1996). Moreover, there were no significant differences in soil properties between moisture treatments. The highest exchangeable $\mathrm{Ca}$ content was recorded in the $\mathrm{C}-0$ treatment. There were significant differences in exchangeable $\mathrm{Ca}$ content between $\mathrm{C}-0$ and $\mathrm{C}-1$ as well as between $\mathrm{C}-2$ and $\mathrm{C}-3$ treatments (Figure 2). Aluminum in the soil had a significant negative correlation with exchangeable $\mathrm{Ca} \quad\left(\mathrm{r}=-0.947^{* * *}\right.$, $p<0.001)$.

Moreover, the results of Tukey's test revealed that the soil aluminum content was significantly different between all of the aluminum treatments (Figure 2); the highest $\mathrm{Al}$ content was noted in the $\mathrm{C}-3$ treatment.
However, there were no significant differences in aluminum content between moisture treatments (Figure 2). In addition, Suthar et al. (2008) reported that the moisture content in soils also influences the bioavailability of metals in earthworms.

Soil $\mathrm{pH}$ was significantly positively correlated with soil aluminum content and aluminum content in the earthworms $\left(\mathrm{r}=0.798^{* * *}, p<0.001\right.$ and $\mathrm{r}=0.828^{* * *}$, $p<0.001$, respectively). Suthar et al. (2008) also observed positive correlations between soil properties (e.g., $\mathrm{pH}$, organic $\mathrm{C}$ and total $\mathrm{N}$ ) and the metal content of earthworms. Moreover, van Gestel and Hoogerwerf (2001) observed that aluminum was most toxic at a $\mathrm{pH}$ of 3.4 (LC50=589 $\mathrm{mg} \mathrm{Al} \mathrm{kg}^{-1}$ dry soil). Lastly, an aluminum $\mathrm{x}$ moisture interaction has not been found in soil measurements. 


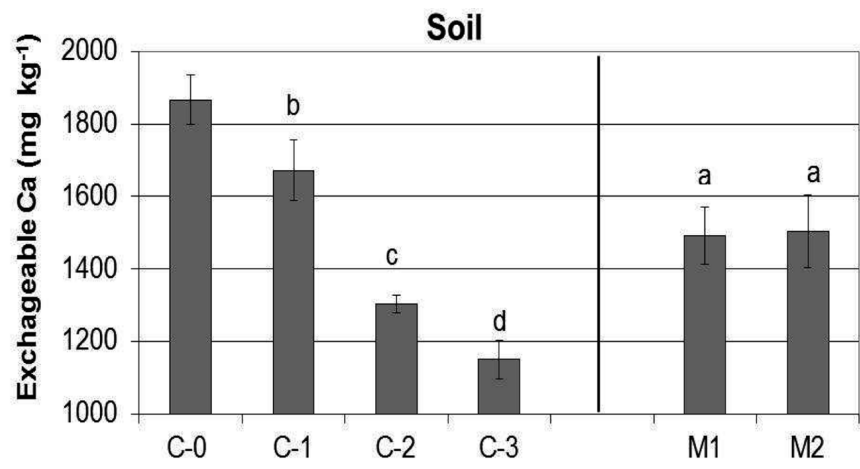

Aluminum level

Moisture level

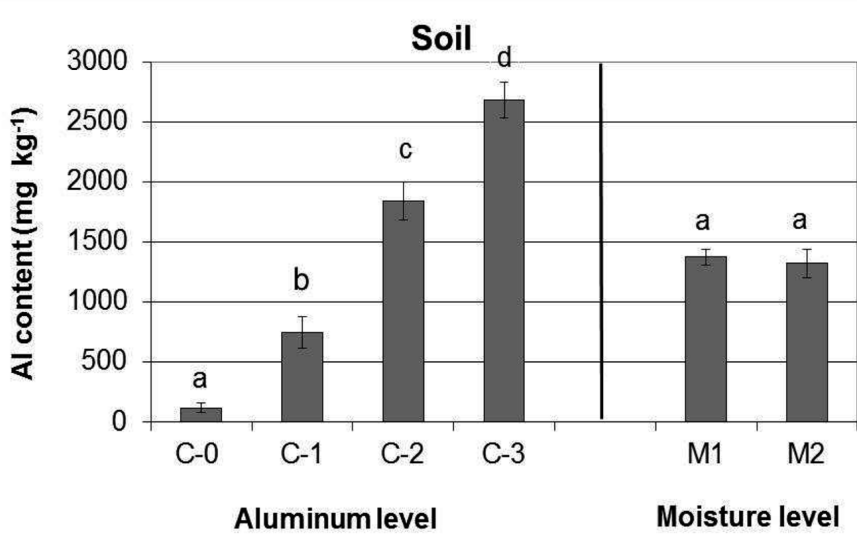

Figure 2. Effects of aluminum treatments (C-0: $\left.0 \mathrm{mg} \mathrm{kg}^{-1}, \mathrm{C}-1: 1000 \mathrm{mg} \mathrm{kg}^{-1}, \mathrm{C}-2: 2000 \mathrm{mg} \mathrm{kg}^{-1}, \mathrm{C}-3: 3000 \mathrm{mg} \mathrm{kg}^{-1}\right)$ and moisture level (M1: $100 \%$ soil water capacity, $M 2: 60 \%$ soil water capacity) on soil exchangeable $\mathrm{Ca}\left(\mathrm{mg} \mathrm{kg}^{-1}\right)$ and $\mathrm{Al}$ content $\left(\mathrm{mg} \mathrm{kg}^{-1}\right)$. For each factor, columns followed by the same letter are not significantly different $(p \leq 0.05$, Tukey test). Bars indicate standard error.

\subsection{Earthworms}

Earthworms have a high potential for accumulating heavy metals from contaminated soils (Garg et al., 2009; Vandecasteele et al., 2004). Our results indicated that the lowest aluminum concentration in earthworms was found in the C-0 treatment (Figure 3). Tukey's test revealed significant differences between the $\mathrm{C}-2$ and $\mathrm{C}-3$ treatments. The highest aluminum content in earthworms was observed in the C-3 treatment. In addition, the highest $\mathrm{N}$ content was recorded in the
C-0 treatment. There were no significant differences between the C-2 and C-3 treatments (Figure 3). The aluminum content in the earthworms was significantly positively correlated with the aluminum content in the soil $\left(\mathrm{r}=0.984^{* * *}, p<0.001\right)$. The highest protein concentration in earthworms was recorded in the C-0 treatment (Figure 4). There were no significant differences between the $\mathrm{C}-2$ and $\mathrm{C}-3$ treatments. Zhang et al. (2013) also observed that the protein content in the earthworms was much higher in the control treatment compared with the aluminum treatments. 

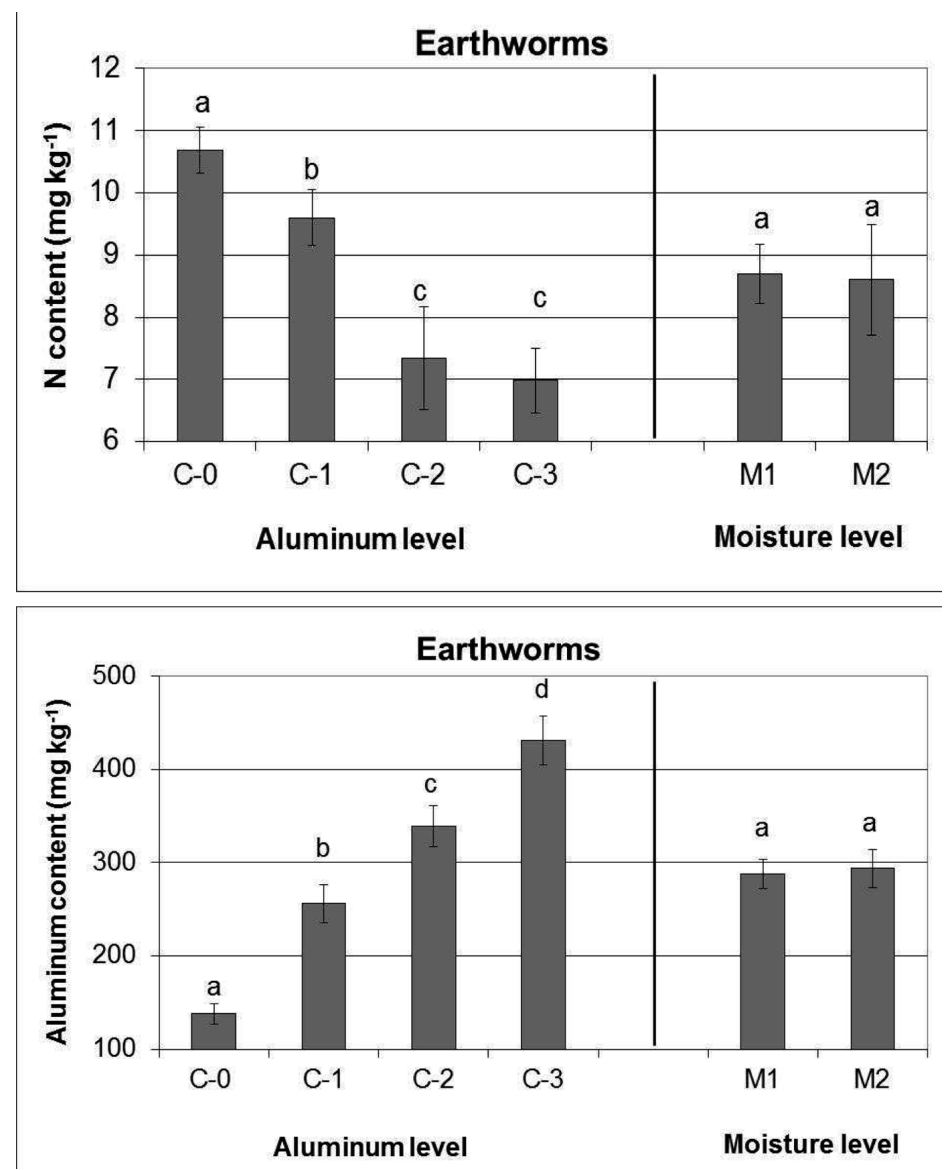

Figure 3. Effects of aluminum treatments (C-0: $0 \mathrm{mg} \mathrm{kg}{ }^{-1}, \mathrm{C}-1: 1000 \mathrm{mg} \mathrm{kg}^{-1}, \mathrm{C}-2: 2000 \mathrm{mg} \mathrm{kg}^{-1}, \mathrm{C}-3: 3000 \mathrm{mg}$ $\mathrm{kg}-1$ ) and moisture level (M1: 100\% soil water capacity, M2: 60\% soil water capacity) on the $\mathrm{N}$ and aluminum content $\left(\mathrm{mg} \mathrm{kg}^{-1}\right)$ of earthworms. For each factor, columns followed by the same letter are not significantly different $(p \leq 0.05$, Tukey test). Bars indicate standard error.

Moreover, there were no significant differences in earthworm traits between moisture treatments. The protein concentration was significantly negatively correlated with the soil aluminum content $(\mathrm{r}=-0.957 * * *$, $p<0.001$ and $\mathrm{r}=0.828^{* * *}, p<0.001$, respectively). The growth of earthworms was affected by the Al level (Figure 5); the weight of the earthworms was highest under the C-0 treatment. Tejada et al. (2010) also reported that earthworm weights decrease with time and with an increase in the $\mathrm{Al}$ concentration in polluted soil. Moreover, Zhang et al. (2013) observed that the growth of the earthworm Eisenia fetida was significantly increased at the lowest $\mathrm{Al}$ concentration, whereas high $\mathrm{Al}$ concentrations retarded the growth of earthworms. No mortality was observed in soil contaminated with Al. These results are in accordance with those of Tejada et al. (2010), who studied the toxicity of $\mathrm{Al}$ in the earthworm Eisenia fetida. 


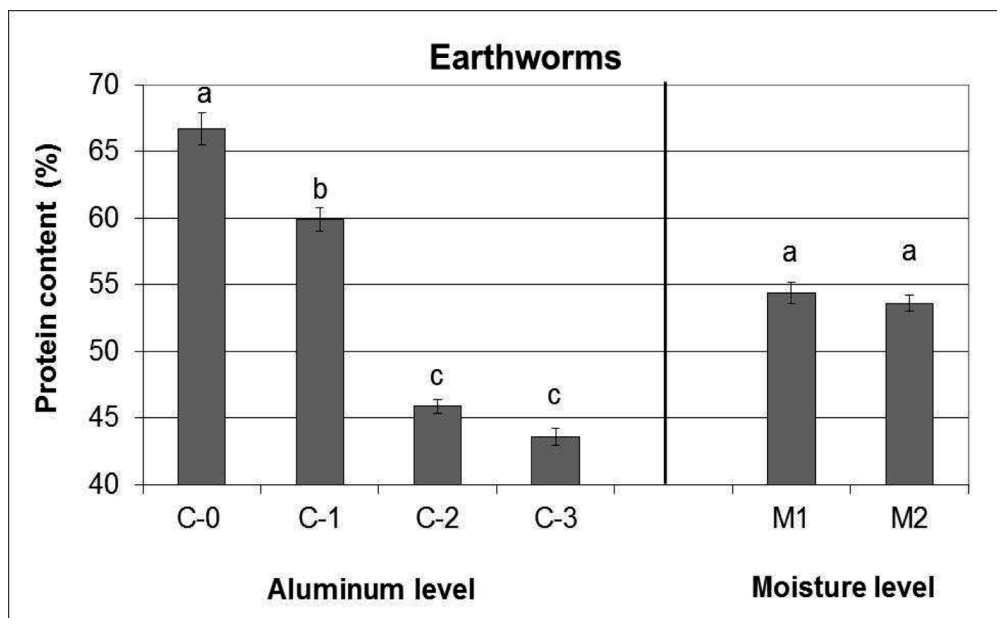

Figure 4. Effects of aluminum treatments (C-0: $0 \mathrm{mg} \mathrm{kg}{ }^{-1}, \mathrm{C}-1: 1000 \mathrm{mg} \mathrm{kg}^{-1}, \mathrm{C}-2: 2000 \mathrm{mg} \mathrm{kg}{ }^{-1}, \mathrm{C}-3: 3000 \mathrm{mg}$ $\left.\mathrm{kg}^{-1}\right)$ and moisture level (M1: $100 \%$ soil water capacity, $M 2: 60 \%$ soil water capacity) on the protein content (\%) of earthworms. For each factor, columns followed by the same letter are not significantly different ( $p \leq 0.05$, Tukey test).

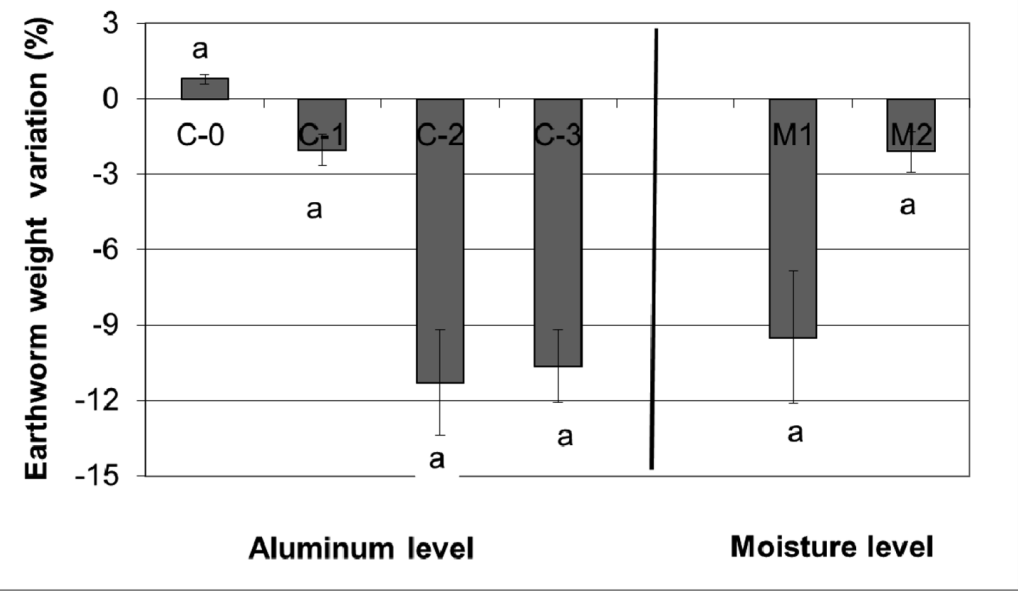

Figure 5. Earthworm weight variation during the experiment (\%). For each factor, columns followed by the same letter are not significantly different $(p \leq 0.05$, Tukey test). Bars indicate standard error. 
In addition, Zhang et al. (2012) observed that the survival rate of E. fetida was $80 \%$ in 14 days and $60 \%$ in 28 days in the presence of $300 \mathrm{mg} \mathrm{Al} \mathrm{kg}^{-1}$. Heavy metals influence the growth and mortality of the earthworms. Garg et al. (2009) reported 100\% mortality in Eisenia fetida and Allolobophora parva at all concentrations of $\mathrm{Cu}$ tested $(500,1500$ and $\left.2500 \mathrm{mg} \mathrm{kg}^{-1}\right)$.(Table 1)

Table 1. Correlation coefficients ${ }^{1}$ between soil properties and earthworm characteristics.

\begin{tabular}{lc}
\hline & R coefficient \\
\hline Aluminum in the earthworms x aluminum in soil & $0.984^{* * *}$ \\
pH x aluminum in soil & $0.798^{* * *}$ \\
pH x exchangeable Ca & $-0.79^{* * *}$ \\
pH x aluminiumminum in the earthworms & $0.828^{* * *}$ \\
Aluminum in soil x exchangeable Ca & $-0.970^{* * *}$ \\
Aluminum in the earthworms x exchangeable Ca & $-0.947^{* * *}$ \\
Aluminum in soil x earthworm protein & $-0.957^{* * *}$ \\
Aluminum in the earthworms x earthworm protein & $-0.953^{* * *}$ \\
\hline
\end{tabular}

${ }^{1} \mathrm{r}$ was calculated using the linear equation. ${ }^{* * *}$, significant at $p=0.001$.

\section{Conclusions}

In the current study, the highest aluminum content in earthworms was observed in the C-3 treatment. There were no significant differences in soil properties between moisture treatments. Moreover, there were no significant differences in electrical conductivity, cation exchange capacity or total nitrogen between the aluminum treatments. In addition, the highest exchangeable $\mathrm{Ca}$ content was recorded in the $\mathrm{C}-0$ treatment (control). The aluminum content in the earthworms was significantly positively correlated with aluminum content in the soil $(\mathrm{r}=0.984 * * *$, $p<0.001)$. Moreover, no mortality was observed in soil contaminated with Al. There were no significant differences between the aluminum treatments with respect to the weight of the earthworms. The earthworm Octodrilus complanatus has been found to accumulate large quantities of aluminum.

\section{References}

Bilalis, D., Sidiras, N., Vavoulidou E., Konstantas A. 2009. Earthworm populations as affected by crop practices on clay loam soil in a Mediterranean climate. Acta Agric. Scand. Sect. B- Plant Soil Sci. 59, 440-446. 
Bradford, M.M. 1976. A rapid and sensitive method for the quantitation of microgram quantities of protein utilizing the principle of protein dyebinding. Analytical Biochemistry. 72, 248-254.

Bremner, J.M. 1960. Determination of nitrogen in soil by Kjedahl method. J. Agric. Sci. 55, 11-33.

Bullinger-Weber, G., Guenat, C., Salomé, C., Gobat, J.M., Le Bayon, R.C. 2012. Impact of flood deposits on earthworm communities in alder forests from a subalpine floodplain (Kandersteg, Switzerland). Eur. J. Soil Biol. 49, 5-11.

Calisi, A., Zaccarelli, N., Lionetto, M.G., Schettino, T. 2013. Integrated biomarker analysis in the earthworm Lumbricus terrestris: Application to the monitoring of soil heavy metal pollution. Chemosph. 90, 2637-2644.

Chapman, H.D. 1965. Cation-exchange capacity. In: C. A. Black (ed.) Methods of soil analysis Chemical and microbiological properties. Agron. 9, 891-901.

Dureja, P., Patra, D., Johnson S., Tomar, S.S. 1999. Effect of agrochemicals on earthworms. Toxicol. Environ. Chem. 71, 397-404.

Edmeades, D.C., Smart, C.E., Wheeler, D.M. 1983. Aluminium toxicity in New Zealand soils: Preliminary results on the development of diagnostic criteria. N. Z. J. Agric. Res. 26, 493-501.

Garg, P., Satya, S., Sharma, S. 2009. Effect of heavy metal supplementation on local (Allolobophora parva) and exotic (Eisenia fetida) earthworm species: A comparative study. J. Environ. Sci. Health, Part A: Toxic/Hazard. Subst. Environ. Eng. 44, 1025-1032.

Goldberg, S., Davis, J., Hem, J., 1996. The Surface Chemistry of Aluminum Oxides andi Hydroxides. In G. Sposito (ed), "The Environmental Chemistry of Aluminum" CRC Lewis Publishers. Boca Raton.
ISO - International Organization for Standardization. (1998). ISO-11268-2: Soil quality - Effects of pollutants on earth-worms (Eisenia fetida) (Part 2: Method for the determination of effects on reproduction), Genève, Switzerland.

Lapied, E., Nahmani, J., Rousseau , G.X. 2009. Influence of texture and amendments on soil properties and earthworm communities. Appl. Soil Ecol. 43, 241-249.

Leveque, T., Capowiez, Y., Schreck, E., Mazzia, C., Auffan, M., Foucault, Y., Austruy, A., Dumat, C. 2013. Assessing ecotoxicity and uptake of metals and metalloids in relation to two different earthworm species (Eiseina hortensis and Lumbricus terrestris). Environ. Pollut. 179, 232241.

Ma, J.F., Ryan, P.R., Delhaize, E. 2001. Aluminium tolerance in plants and the complexing role of organic acids. Trends Plant Sci. 6, 273-278.

Matsumoto, H. 2000. Cell biology of aluminum toxicity and tolerance in higher plants. Int. Rev. Cytol. 200, 1-46.

Monroy, F., Aira, M., Gago, J.A., Dominguez, J. 2007. Life cycle of the earthworm Octodrilus complanatus (Oligochaeta, Lumbricidae). Comptes Rendus Biol. 330, 389-391.

OECD (2004), Test No. 222: Earthworm Reproduction Test (Eisenia fetida/Eisenia andrei), OECD Guidelines for the Testing of Chemicals, Section 2, OECD Publishing.

Ozawa, T., Risal, C.P., Yanagimoto, R. 2005. Increase in the nitrogen content of soil by the introduction of earthworms into soil. Soil Sci. Plant Nutr. 51, 917-920.

Pavlíček, T., Csuzdi, C. 2006. Species richness and zoogeographic affinities of earthworms in Cyprus. Eur. J. Soil Biol. 42, S111-S116. 
Seguel, A., Cumming, J.R., Klugh-Stewart, K., Cornejo, P., Borie, F. 2013. The role of arbuscular mycorrhizas in decreasing aluminium phytotoxicity in acidic soils: a review. Mycorrhiza. 23, 167-183.

Suthar, S., Singh, S., Dhawan, S. 2008. Earthworms as bioindicator of metals ( $\mathrm{Zn}, \mathrm{Fe}, \mathrm{Mn}, \mathrm{Cu}, \mathrm{Pb}$ and $\mathrm{Cd}$ ) in soils: Is metal bioaccumulation affected by their ecological category?. Ecol. Eng. 32, 99-107.

Tejada, M., Gómez, I., Hernández, T., García, C. 2010. Response of Eisenia fetida to the application of different organic wastes in an aluminiumcontaminated soil. Ecotoxicol. Environ. Saf. 73, 1944-1949.

Vamerali, T., Marchiol, L., Bandiera, M., Fellet, G., Dickinson, N.M., Lucchini, P., Mosca, G., Zerbi, G. 2012. Advances in agronomic management of phytoremediation: methods and results from a 10year study of metal-polluted soils. Ital. J. Agron. 7, e42.

van Gestel, C.A.M., Hoogerwerfa, G. 2011. Influence of soil $\mathrm{pH}$ on the toxicity of aluminium for Eisenia andrei (Oligochaeta: Lumbricidae) in an artificial soil substrate. Pedobiol. 45, 385-395.

van Vliet, P.C.J., van der Zee, S.E.A.T.M., Ma, W.C. 2005. Heavy metal concentrations in soil and earthworms in a floodplain grassland. Environ. Pollut. 138, 505-516.

Vandecasteele, B., Samyn, J., Quataert, P., Muy, B., Tack, F.MG. 2004. Earthworm biomass as additional information for risk assessment of heavy metal biomagnification: a case study for dredged sediment-derived soils and polluted floodplain soils. Environ. Pollut. 129, 363-375.
Vavoulidou, E., Avramides, E., Wood, M., Lolos, P. 2009. Response of soil quality indicators to the pesticide cadusaphos. Commun. Soil Sci. Plant Anal. 40, 419-434.

Vavoulidou, E., Dellaporta, L., Bilalis, D.J. 2010. Collagen distribution in the tissue of the earthworm Octodrilus complanatus Zoology in the Middle East. Advances of the 4th International Oligochaeta Taxonomy Meeting Zoology in the Middle East, Supplementum 2, 175-180.

Wang, Q., Yu, Y.L., Li, M., Long, Y.H., Fang, H., Li, S.N. 2009. Indication of soil heavy metal pollution with earthworms and soil microbial biomass carbon in the vicinity of an abandoned copper mine in Eastern Nanjing, China. Eur. J. Soil Biol. 45, 229-234.

Wu, X.M., Yu, Y.L., Li, M., Long, Y.H., Fang, H., Li, S.N. 2011. Prediction of bioavailability of chlorpyrifos residues in soil to earthworms. J. Soil Sci. Plant Nutr. 11, 44-57.

Zhang, J., Yu, J., Ouyang, Y., Xu, H. 2013. Responses of earthworm to aluminum toxicity in latosol. Environ. Sci. Pollut. Res. 20, 1135-1141.

Zhao, L., Qui, J.P. 2010. Aluminum bioaccumulation in the earthworm and acute toxicity to the earthworm. 4th International Conference on Bioinformatics and Biomedical Engineering (ICBBE). pp: 1-4. 